\title{
ÖZGÜR SERENGETİ: AFRİKA YEREL DIINLERINDE HAYVAN HAKLARI
}

\author{
Prof. Dr. Mustafa ALICI*
}

Öz: Hayvan hakları, antropolojik açıdan kültürel öğelerle beslenirken, dinî öğretilerle teolojik açıdan kontrol altına alınmakta, ahlaki açıdan kınayıcı son olarak hukuki düzenlemelerle cezalandırıcı ve bağlayıcı bir şekilde tasnif edilip tam olarak belirlenmektedir. Bu bağlamda Afrika yerel inançları, bir bütün olarak insan, hayvan, bitki, dağ, ırmak gibi canlı veya cansız tüm varlığı kuşatmakta ve onların ontolojik hakkını koruyan bütüncül ve entegre edici bir sisteme dönüşmektedir. Zaten Afrikalının bilinci, canlı derken sadece insanı merkeze almamakta aksine Afrika çevresindeki insan, hayvan ve bitkiyi de içermektedir.

Bu çalışmada Afrika yerel inanç sisteminde hayvan haklarının ekolojik hayat ve biyolojik çeşitlilik açısından karakteristik özelliklerini, ritüelleri, külte dönüşen bu ritüellerin arkasındaki mit ve halk inanışlarını ve son olarak da dinî uygulamalara yönelik çağdaş eleştiriler ele alınacaktır.

Anahtar Kelimeler: Afrika, hayvan hakları, ahlak, dinler tarihi, ekoloji

\section{FREE SERENGETI: THE ANIMAL RIGHTS IN \\ THE AFRICAN INDIGENOUS TRADITIONS}

Abstract: As animal rights are fed by phenomena that come from anthropological contexts, theoretical assessment about them are to be taken under control with religious dogmatic teachings along with the moral economic condemnation determined by punishment and binding in legal regulations. In this respect, The indigenous belief systems of Africa, as a whole, embrace all the living and inanimate beings, as wide spectrum from human beings to animals and plants and even to mountains and rivers; by this way this belief system becomes an integrated and holistic system protecting their ontological rights. As a matter of fact, the consciousness of the African people does not only focusing on the human kind but also includes the animals and the plants all around the African environment.

In this article, we will consider the main characteristics of African Indigenous belief systems that they give a wide place to animal rights, their features of ecological lives and biological diversity as well as their rituals, myth and folklores that form these ritual cults, and finally contemporary critiques dealing about these religious practices.

Key Words: Africa, animal rights, ethics, the history of religions, ecology.

\section{Giriş}

Bilinç ve vicdan sahibi yardımsever insan, her şeyiyle bu dünyaya aittir,

ORCID ID : 0000-0001-9513-6768

DOI : 10.31126-akrajournal.743010

Geliş tarihi : 26 Mayıs 2020 / Kabul tarihi: 30 Ağustos 2020

*Erzincan Binali Yıldırım Üniversitesi, İlahiyat Fakültesi, Dinler Tarihi Ana Bilim Dalı. 
canlı ve cansız tüm varlıklara karşı kendi doğasına ait özellikleriyle bu özelli ğini göstermek istemektedir. Antropolojiye göre insanın tüm özellikleri ve hakları, gerçek bir hayat yaşaması için şarttır. ${ }^{1} \mathrm{Bu}$ yönde modern antropoloji; insanoğlunun teknik alet yapabilmesini, belli bir inanç ve kanaat sahibi olmasını soyut düşünebilmesini ve bunu sözle aktarabilmesini diğer canlı varlıklardan bilhassa en yakın biyolojik varlıklar olan hayvanlardan ayrıştıran özellikleri görmektedir.

Buna karşın çağdaş bazı evrimci antropologlar (özellikle primatologlar), hiçbir kıtada olmayacak kadar vahşi doğasıyla açık savanalara ve burada yaşayan zengin hayvan türlerine sahip Afrika'da bazı şempanzelerin sadece alet kullanmakla kalmadıklarını aynı zamanda onları ustalıkla yapabildiklerini kanıtlamışlardır. Yine diğer bazı antropologlar ise bazı maymun ve goril türlerinin eğitildikleri takdirde işaret dili veya bilgisayar klavyesi yardımıyla insanlarla kabaca iletişim kurabileceklerini ve hatta kültürel dili aktarabileceklerini düşünmektedirler. ${ }^{2}$

Dinler tarihi açısından baktığımızda Hinduizm ve Budizm gibi Doğu dinleri, ruhların hayvanlara geçiş yaptığına dolayısıyla hayvanların da ruhlarının olduğuna inanırken Yahudilik, Hristiyanlık ve İslam gibi ilahi dinler ise insanın ruhu olabileceğini hayvanların ruh taşımayacaklarını en azından ilahi ruhlarının olamayacağını vurgulamaktadırlar. ${ }^{3}$ Pozitivist Darwinist evrimci biyoloji ise hem hayvanların hem de insanların ortak bir atadan var olabileceği faraziyesini iddia etmektedir.

Bunun yanında insanlık tarihi boyunca hayvanlar tarım ve hizmet hayvanları manda, sığır, at, eşek, deve...vb.; insana yardımcı hayvanlar köpek, kedi, güvercin, bazı yırtıcı kuşlar...vb.; süs ve sirk hayvanları aslan, kaplan, fil, yunus balıkları...vb. tasniflere ayrılmıştır. ${ }^{4}$

Günümüzde herhangi bir dinî inanç veya kanaatle sınırlandırılmadan seküler ahlaki kurallarla tüm canlılara karşı çok boyutlu davranışlar geliştirmek isteyen çağdaş ahlak felsefeleri baskın şekilde kimlik verici özellikleri konu edinmektedirler. ${ }^{5}$ Söz gelişi öznel kimliğe vurgu yapan ve insan-doğa, insanhayvan veya ruh-doğa diyalektiğini işleyen postmodern eleştirel düşünce

1. Grivas Kayange - Simon Makwinja, "Exploring the Ethical Basis of Animal”, Journal of Humanites(Zomba), 24 (2016), s. 29.

2. Lisa Yount, Animal Rights, (New York: Infobase Publishing, 2008), s. 7-8.

3. James A. Spell, “Attitue Towards Animals." Encyclopedia of Animal Rights and Animal Walfare. Ed. Marc. Bekoff. (Westport: Greevwood Press, 1998) s. 76-78.

4. Clifford J. Sherry, Animal Rights-A Reference Handbook, (New York: Greenwood, 2009), XIX- 1 .

5. Jane Goodall, "Foreword", Encyclopedia of Animal Rights and Animal Welfare, (Westport: Greenwood Press, 1998), IX. 
ise (mesela Derrida, Ricoeur veya Heiddegger) normatif süje ile insanın kendi evrenini oluşturmasını vurgularken insanı diğer canlılardan bilhassa hayvanlardan kesin bir şekilde ayrıştırmaya çabalamakta ve çok boyutlu doğa ve evrene ait postmodern özneyi önemsemektedirler. ${ }^{6}$

Çağdaş ahlak felsefecileri eğitmek maksadıyla hayvanlara işkence etmek, cezalandırmak, şiddet uygulamak gibi ihlallere karşı cephe alarak öne çıkarlar. Bu ihlalleri ortadan kaldırmak üzere geliştirilen hayvan hakları ise doğal yaşam hakları çerçevesinde ortaya çıkan yaşamı kolaylaştırıcı temel faktörleri ortaya koymaktır. Bilinçli olarak ortaya konan hayvan hakları arasında onlara şefkat gösterip sevmek, çoğalmalarına imkân sağlamak, uygun çevre, yiyecek ve barınma imkânına kavuşturmak, gerçek saygıyı göstermek gibi yaşamlarını kolaylaştırıcı imkânların sağlanması bulunmaktadır.'

Böylece hayvanların en doğal hâliyle hakları, insani gerekçelerle antropolojik ve kültürel açıdan, dinî öğretilerle teolojik açıdan, ahlaki düşünceyle k1nayıcı ve hukuki düzenlemelerle cezalandırıcı açıdan bağlayıcı bir şekilde tasnif edilip tam olarak belirlenmektedir.

$\mathrm{Bu}$ çalışmada hayvan hakları açısından Afrika yerel inanç sisteminin ekolojik hayatı ve biyolojik çeşitliliği koruyucu karakteristik özellikleri, bu bağlamda ahlaki yönelimler 1şığında ortaya çıkan ritüeller, külte dönüşen bu ritüellerin arkasındaki mit ve halk inanışları ve son olarak bu yönde ortaya çıkan hak ihlalleri veya eleştiriler ele alınacaktır.

\section{Afrika Yerel Dinlerinin}

\section{Biyo-Ekolojik ve Çoklu Animatif Özellikleri}

Afrika'nın yerel yerli geleneklerinin "din" olarak sayılıp sayılmayacağı bilhassa evrimci antropolojilerin, monoteizm bulma peşindeki din tarihçilerinin ana uğraşı olmuştur. Bilhassa misyoner hedeflere hizmet eden antropolojinin, bu gelenekler için bulduğu en önemli sıfatlar, "ilkel dinler" ve "erken kültürler" terimleri oldu. Öncelikle bilmeliyiz ki Afrikalı için din kelimesi Batılılar için kastedilen şeyden farklı veya yabancı olabilmektedir. Bu yaftalama tıpkı dinler tarihçilerinin Konfüçyanizm ve Taoizm'i "hayat felsefeleri” olarak anlamasina benzetilebilir. ${ }^{8}$

Ana hatlarıyla gündelik hayatın etnografik fenomenolojisi diyebileceğimiz

6. Caroline Rooney, African Literature, Animals and Politics, (London: Routledge Publishing, 2003), s. 100.

7. Julian H. Franklin, Animal Rights and Moral Philosophy, (New York: Columbia University Press, 2005), s. 1-123.

8. Edward, P. Antonio, "Indigenous African Traditions as Models for Theorizing Religion", Religion Theory Critique-Classic and Contemporary Approaches and Methologies, ed. Richard King, (New York: Colombia University Press, 2017), s. 147-148. 
bir din bilimi çalışması dinamik Afrika “din (religio)” anlayışının Batılı din tanımlardan farklılıklarını şu şekilde maddeleştirilebilir:

a. Bu gelenekler, gündelik hayat, yeme- içme, avlanma hatta dans etme gibi konularda Batılı sosyo-kültürel açıdan farklıdırlar.

b. Bu gelenekler kolayca din terimi altında evcilleştirelemeyecek kadar başkadir.

c. Afrikalı için ritüel, ahlak ve sosyal organizasyonlar din kategorisi dışında olacak kadar beșeri fenomenlerdir.

ç. Afrika din olgusu, evrensel veya bölgesel veyahut ulusal olmayacak kadar yereldir.

d. Bu açıdan Afrika yerel gelenekleri, din dışı (profan) veya seküler kategorilerini de aşacak şekilde "beşerî sağ duyu perspektifleri veya gündelik hayat anlayışları olarak düşünülebilir.

e. Bu gelenekler bir başka boyutuyla kişilik, topluluk, konukseverlik ve sağlık gibi hümanist değerler taşıyan ve insanlar ile doğa, ruhlar ve ilahlar arasındaki yakın ilişkileri anlatan "antropolojik hümanizm (ubuntuizm)" kabul edilebilir.

f. Bu geleneklerin klasik dinlerden en büyük farklardan biri de ruhani aç1dan sosyal güçlerin metafizik âlemle interaktif ilişki kurup cemiyete ve bireye ait sorunlara çareler aramasına önem vermesidir. Buna ilave olarak kötü ruhlar vasıtasıyla bu âleme düşman olma veya yabancılaşma gibi aykırı durumların ortadan kaldırılmasını amaçlayan bu gelenekler, ahlaki açıdan ölü ataların uygulamalarını önemseyerek onlarla daha sıcak iletişim kurmayı (kehanet) öne çıkarıp yaygınlaştırmaktadırlar. ${ }^{9}$

Afrika, farklı ekolojik canlı çeşitliğine bilhassa tür yelpazesi açısından çok zengin hayvanlara sahip olan bir kıtadır. Biyo-ekolojik açıdan Afrika yerli dinleri de genel olarak Afrika dünyasının izole edilmiş kültürel havzaları olarak düşük orandaki topluluklarına ait ortak hayat görüşlerini ve iş bölümlerini yansitmaktadır. Bu dinlerin ortak temel zihinsel meşguliyetleri, tüm doğallığıyla hayatın ortak, iyi, uyum ve birbirleriyle ilişkileri üzerinedir. Bu dinlerde Yüce Tanrı inancı olan, ama düşük ilahlara, ata ve doğa ruhlarına yer veren henoteist bir bakış açısı olduğu söylenebilir. Bir başka ortak nokta olarak Afrika yerli inançları, küresel/evrensel dinlerin sahip oldukları kutsal kitaplardan yoksun olmasına rağmen, sözel olarak aktarılan mitolojileri, efsaneleri, inançları, atasözleri, hikmetleri, değerleri ve örfleri bulunur. Bu açıdan bu ortak özellikleri sebebiyle Batılıların aksine Afrika kökenli bilim adamları yerel gelenekleri "tek bir dinî sistem" olarak görme eğilimindedirler. ${ }^{10}$

9. Antonio, s. 148-153.

10. Kai Horsthemke, Animals and African Ethics, (New York: Palgrave Macmillan Publishing, 2015), s. 8. 
Dolayısıyla karakteristik açıdan Afrika yerel inançlarının biyo-etik açısından daha az insan merkezli inançlar geliştirdiğini ve hayvanlar başta olmak üzere canlılara değer veren, koruyucu, kollayıcı bir tarzda daha düşük seviyede insan lehine olmakla beraber daha çok doğal hedefler peşinde olduğunu söyleyebiliriz. Dolayısıyla hemen hemen Afrika'daki her yerli toplumun hayvanları kollayan, koruyan, onların lehine olan sıradan hayatı ifade eden kurallar geliştirdiği gözlemlenebilir bir gerçekliktir. ${ }^{11}$

$\mathrm{Bu}$ bakımdan Batılıların yaftalamasına rağmen Afrika'da Animizm'in en basit ifadeyle bir din değil aksine Afrika yerel kültürlerinde belki işlevsel olarak bu dünyayı oluşturmak üzere bir dereceye kadar etki etmiş metafizik bir faktör olduğu söylenebilir. Buna göre manevi ve maddi âlemleri bir noktada toplayan Afrikalı insanlar, kutsal ile seküler olanı, ruh taşıyan ile ruh taşımayanı birbirinden ayırt etmeyerek tümünün bir canlı olduğuna inanmaktadırlar ${ }^{12}$

Bir başka biyo-ekolojik özelliğiyle Afrika'nın bazı dinleri, tanrılar ve tanrıçaları hayvan formlarında konuşturan ve hikmetli sözler söyleten inanç sistemleridir. Bir başka ifadeyle bazı Afrikalı tanrılar, tıpkı temsil ettikleri bir veya birden fazla hayvanın formuna girmekte -söz gelişi kartalın keskin gözlerine sahip olarak nitelenmekte- inananlarına çok boyutlu hayatın alanlarına yönelik olarak yardım etmektedirler. Hatta ölü ataların, "hayvan formunda" yer altı dünyasındaki ruhlar âlemine inerek ruhani desteğe muhtaç olan insanlara yardıma götüreceklerine inanılmaktadır. ${ }^{13}$

Buradan hareketle Afrika geleneksel dinlerinin genel olarak özü itibariyle doğal çevreye ait canlılara olumlu bakan, temelde hayvanlara dostça yaklaşan bir inanç sistemi olduğu söylenebilir. Dahası Afrika geleneksel dinlerinin ekolojik tavrı, iki yönlüdür: Bir tarafta ata ruhlarından korkarak saygı duymak, diğer taraftan doğaya sevgi dolu hürmet etmek. Dolayısıyla bu inancın oluşmasında hem ölü ruhlar ve ilahların gücünün hem de doğanın mevcut durumunun büyük katkı sağladığı söylenebilir. ${ }^{14}$ Böylece irmaklarda, yağmurlarda, ormanlarda, gökte, yıldırımda ve doğal yaşamdaki hayvanlarda tanrıların bulunduğunu kabul etmek yerlilere dinî tecrübe açısından ruhani ve esrarengiz bir güç duygusu kazandırmaktadır. Bu anlayışa göre yerliler ve hayvanlar sanıldı̆̆ı gibi "vahşi değil”, doğal ve spontane bir hayat yaşamaktadırlar. ${ }^{15}$

11. Kayange - Makwinja, "Exploring the Ethical Basis of Animal", s. 32.

12. Molefi Kete Asante, "Animism", Encyclopedia of African Religion, ed. Molefi Kete Asente - Ama Mazama, (California: Sage Publishing, 2009), s. 58-59.

13. Willie Cannon - Brown, "Bull”, Encyclopedia of African Religion, ed. Molefi Kete Asente - Ama Mazama, (California: Sage Publishing, 2009), s. 141.

14. Nisbert Taringa, "How Environmental is African Traditional Religion?", Exchange, 35/2 (2006), s. 191-194.

15. Ninian Smart, Religions of the West, (New Jersey: Prentice Hall, 1994), s. 247. 
Afrika'nın geleneksel dinlerinde tüm hayvanlar başta olmak üzere, bitkiler ve su kaynakları öncelikle kutsaldır ve ontolojik açıdan en yüce değer olan kutsiyet ile onore edilirler. Zira âlemde bilhassa yeryüzünde ve insanlarda yaratılışın hayati aracıdırlar. Bu bakımdan en saygın yere sahip olarak bazı hayvanlar, bizzat ilahlar olarak kabul edilirken bazıları ise belli başlı ilahları sembolik olarak temsil ederler. Pratik açıdan hayvanlar, insanlara doğanın bir parçası olarak yaşam kaynağı olarak hayat bahşederken totem olarak ise sosyal hayatın işleyişini kolaylaştırırlar. Bu bakımdan Afrika ritüel hayatında hayvanlara ait simge veya imgeler, bilhassa öykülerde, tekstillerde, evlerde, tapınaklarda, türbelerde, mutfak eşyalarında, davullarda, heykel veya resimlerde "kutsal objeler" olarak özel yer tutarlar. ${ }^{16}$

Dolayısıyla Afrika yerli dinlerinin, aydınlanmacıların aramış olduğu Doğal Din (Religio Naturalis) portresi olduğu söylenebilir.

Öyle ki bu dinin doğaya yönelik birbiriyle ilintili üç yaklaşımı bulunmaktadır: mek.

1. Doğayı tüm çeşitliliği ve zenginliğiyle sürdürülebilir bir yaşam alanı gör-

2. Doğayla çatışmayıp ona boyun eğmek.

3. Doğanın kurallarına göre spontane hareket etmek.

İlk iki yaklaşım, doğanın kutsal boyutlarıyla ilintili olup öncelikle güçlü ata ruhlarından misilleme korkusuna dayanmaktadır. Doğanın korunması ve ona boyun eğmenin sayg1 ve sevgiyi getireceğine duyulan inanç, ahlaki zorunlulukların doymasına yol açmış olabilir. Üçüncü yaklaşım ise aksine doğayı kutsallığından çıkarıp onu tüm organik mevcutlarıyla ve unsurlarıyla sıradanlaştırmak veya profanlaştırmaktır. Bu yaklaşım sayesinde insanlar, dinin kısıtlayıcı ve korkutucu alanından sıyrılıp insanileşmekte hatta doğal hayata karışıp onlarla kaynaşmaktadırlar. Daha radikal bir ifadeyle bu anlayış sayesinde insanlar, özgürce doğayı kullanabilmekte, avlanabilmekte -bize göre- suiistimal edebilmekte hatta herhangi bir kutsallık ve misilleme korkusu olmadan veya saygıya muhtaç olmadan can alabilmektedir. Böylece Afrika kıtasına ait karmaşık inanç sistemleri, dünya görüşleri, kültleri ve buna bağlı oluşan zengin kültürler, çevreye ve bilhassa hayvanlara yönelik dostça yaklaşımlar geliştirebilmektedirler. $^{17}$

\section{Hayvanlarla İlgili Eko-Şamanik Ritüeller}

Afrika'nın konukseverlik ve dayanışma prensipleri sadece insanoğluna değil, aynı zamanda tüm ihtişamıyla doğal dünyaya da hitap eder. Nitekim Af-

16. Denis Martin, "Animal Images", Encyclopedia of African Religion, ed. Molefi Kete Asente - Ama Mazama, (California: Sage Publishing, 2009), s. 54.

17. Taringa, "How Environmental is African Traditional Religion?", s. 211-213. 
rika'nın geleneksel dinlerinde Yüce Varlık fikri, ekolojik bir teoloji olarak sadece insanların değil, aynı zamanda hayvanların ve doğal dünyanın da babası (Sha-Bantu-Ne-Bintu) şeklinde uzun bir sıfat taşımaktadır. Aynı zamanda bu inanç, teolojisini hayvan haklarını gözetme, ekolojik dengeye saygı gibi ilkesel temellere dayandirmaktadır. ${ }^{18}$

Afrika enerji, dinamizm ve hayatın dengeli olduğu, insanlar ve hayvanların doğa ile bütünleştiği bir yerdir. Afrika'nın yerli inançlarında ruhların, mevcut uyumu korumak için var oldukları unutulmamalıdır. Yüce Tanrı genel olarak yaşayan ilk ataya nispet edilerek ehümerizm (tarihî kahramanları ilahlaştırma) bağlamında dinî bir eyleme dönüştürülür. Söz gelişi Akan yerlileri için Yüce Tanrı, Büyük Ata'dır. Ancak Yoruba, Zulu veya Gikuyu gibi yerel toplumlara ait Yüce Tanrı'nın kurtarıcı veya koruyup rızık verici sıfatlarla hayata aktif olarak katılmamaktadır. Bir başka ifadeyle ilahi dinlerdeki Tanrı gibi dünyaya müdahalesi söz konusu değildir. Aksine bu Yüce Varlık, bu âlemi tüm canlılarıyla beraber yaratmış ve bilhassa insanın işlerine müdahale etmeyi tamamen bırakmıştır. Hatta Afrika'nın bazı yerlerindeki inançlara göre Yüce Tanrı, yaratma işlemini bitirmemiş ve bunu tamamlaması için daha aşağıda bulunan ilahlara bırakmıştır. Bu bakımdan Yüce Tanrı'ya ait olmak üzere Afrika'nın hiçbir yerinde tapınak bulunmamakta bunun yerine daha düşük seviyedeki ruhlara mabet olmadan ibadet edilmektedir. ${ }^{19}$

Biyo-ekolojik açıdan Afrika'nın zengin bir doğal çevreye sahip olması Şaman kültürüne de yansımıştır. Şamanik Afrika'da insandan arındırılmış ve hatta negatif açıdan yasaklanmış anlamında kullanılan kutsal terimi ile tabu hâline sokulan kutsal alanlar bilhassa çalı ağaç kümeleri veya koruluklar mevcuttur. Uganda veya Tanzanya gibi ülkelerde çokça görülen bu tür mukaddes koruluklar, çeşitli bitkilerin yanı sıra barındırdığı her türlü hayvan ve zengin böcek çeşitleri tarihsel açıdan mukaddes emanet kabul edilmektedir.

Kutsal sayılan korulukların bütün barındırdığı canlılarla Afrikalıların geleneksel inanç sistemindeki önemi, özellikle yaşama sağladığı kaynaklarla ve insanileşmeye verdiği dinamik katkılarla ölçülebilir. Bir tarafta hayvanların barındıkları bu alanların sembolik açıdan ölmüş ataların ruhlarına veya ilahlara ev sahipliği yaptığı inancı mevcuttur. Böylece buradaki doğal yaşamdaki hayvanlar da otomatik olarak mukaddes hâle dönüştürülmektedir. Diğer taraftan bu alanların tıp veya gıda kaynağı olarak dinamik önemi öne çıkmaktadır. Bu alanlara uygulanan üreme veya ölü ritüellerine baktığımızda koruluklardaki

18. Mutumbo Nkulu-N'Sengha, "God", Encyclopedia of African Religion, ed. Molefi Kete Asente - Ama (California: Sage Publishing, 2009), s. 292.

19. Molefi Kete Asente- Ama Mazama, "Introduction", Encyclopedia of African Religion, ed. Molefi Kete Asente - Ama Mazama, (California: Sage Publishing, 2009), XXIII. 
gezgin hayvanlar dokunulmaz hâle gelmektedir. Hatta pek çok Afrika dinleri uzmanına göre ekolojik açıdan korulukların da ötesinde Serengeti gibi evcilleştirilmemiş hayvanların yaşadığı doğal alanlar, o bölgenin sakinleri tarafından yaşam ve sosyalleşme alanlarına dönüştürülmüştür. ${ }^{20}$

Bu açıdan Afrika'da yasaklanmış "tabu” şeklinde anlaşılan mukaddes terimi etrafında şekillenen doğal yaşama ait dağlar, ırmaklar, ağaçlar, bitkiler ve hayvanlar mevcuttur ve bunlar İlahi varlığın doğadaki tezahürleri olarak değerlidirler. Bu açıdan Afrika'da hayvanlar, bu doğal yaşam içinde en derin saygıya layık olarak ruhani, doğal ve insani ekoloji içinde en spontane formlarıyla yaşam sürerler. Bu bağlamda Afrika insanı biyo-çeşitliliği korumak üzere tasarlanmış kültürel ve dinî kodlara sahiptir. Bu açıdan bakıldığında burada yaşayan dindar insanların ritüel eylemlerinde doğaya ve doğadaki hayvanlara saygı aynı zamanda koruma refleksiyle çalışmaktadır. Çevresel sorunların olmadığ 1 bu alanda hayvanları tehdit eden krizler de yoktur. Zira en geniş anlamıyla doğaya ait olan Afrika inanç ve uygulamaları, ağaçlık alanları geliştirmek, hayvan popülasyonunu dengede tutmak gibi çevresel krizlere çözüm üretmeye elverişli teolojik söylemlere sahiptir. ${ }^{21}$

Mali'de yaşayan Bamana yerlilerine göre antilop türü olan Chiwara adlı tanrı, mitolojik bir anlayışla insanlara tarım yapmayı öğretmiştir. Bu yerlilere göre tarım en önemli meslek olduğundan antilop formundaki bu tanrıya özel tapınma kültleri geliştirilmiştir. Yerli halka göre bu hayvan, biyolojik açıdan toprak ile yılanın birleşmesinden yaratılmış kutsal bir varlık olup çeşitli tasvirler veya maskelerle dinî törenlerde önemli bir figür olarak yerini almaktadır. ${ }^{22}$

Afrika halkları, kültürel açıdan hayvanlara olan yakın ilgilerini ve bitmek tükenmek bilmeyen hayranlıklarını daima yansıtmaktadırlar. Hayvanlar, halk hikâyeleri veya atasözlerindeki temel kahramanlardandır. Hayvanlar, tıpkı Ezop masallarında olduğu gibi insan karakterinde olup insanlara bilgelik ve yol gösteren, konuşan ve düşünen varlıklar olarak sunulmaktadır. Buna ilave olarak yerel dinlerin örgüsündeki halk sanatında hayvanların değeri en az insanlar kadar yüksektir. Dolayısıyla hayvanların Afrika dinî kültüründeki en yüksek değerlerden biri de onların beşerin en eski ve en düşünceli formlarını yansıtmasıdır. Buradan hareketle bir insan hayvanlarla yakın ilişki içinde değil ise insani kimliğini tam yansıtamayacağı şeklinde bir temel sonuç ortaya

20. Edward P. Antonio, "Religion and the Environment", The Wiley-Blackwell Companion to African Religion, ed. Elias Kifon Bongmba, (West Sussex: Blackwell Publishing, 2012), s. 140-148.

21. Antonio, "Religion and the Environment", 148-151.

22. Molefi Kete Asante, "Chiwara", Encyclopedia of African Religion, ed. Molefi Kete Asente - Ama Mazama, (California: Sage Publishing, 2009), s. 163. 
çıkmaktadır. ${ }^{23}$

Çağdaş antropolojiye göre yazılı literatürü olmayan kadim toplumlar arasinda hayvanlara yönelik tavırlar genel olarak etnolojik karakterde olup arkeolojik kazılar veya antropologların yerinde gözlemlerine göre bilhassa dinî kültürel uygulamalarda, sanat veya zanaat ürünlerinde ortaya çıkmaktadır. Bu erken dönem kültürlere ait bulgularda hayvanlarla ilintili insani tavırların hem etnolojik kökleri ve hem de teolojik anlamları hatta değer yargılarıly ilişkili ahlaki yönleri bulunmaktadır. Bu bağlamda ortaya konan pek çok çağdaş etnolojik teoriye göre hayvan haklarına ait en gerçekçi veriler, Güney Afrika'daki çalı adamlarına ait kaya sanat çizimlerinde ortaya çıkmıştır. Bu çalı adamlarının hayvan çizimleri, son tahlilde ritüeller olarak törenleri şamanların çok boyutlu bir şekilde trans hâlinde tecrübe ettikleri rüya veya vizyonları yansıtmaktadır. Yine bu çizimlerdeki hayvan figürleri canlı, maddi ve güçlü ruhsal varlıklar olarak temsil edilmiştir. ${ }^{24}$

\section{Hayvanlar Hakkındaki Mitler, Kültler ve Totemik İnanışlar}

Afrika yerel inançlarındaki hayvan-insan birlikteliği sözlü aktarılan mitolojik öykülere de yansımıştır. Mitolojiye göre çok önceleri insanlar ile hayvanların aynı dili konuştukları birbirlerini anladıkları ve birbirleriyle güçlü işbirliği yaptıkları ifade edilmiştir. Zaman içinde bu kabiliyet körelmiş ve sadece özel bazı insanlara söz gelişi şamanlara veya ruhbanlara özgü hâle gelmiştir. Neticede bu iki tür arasındaki iletişim dünyevi anlamda kopmasına rağmen en saygın hâliyle ritüel boyutlarıyla devam etmiştir. Zira karmaşık yapıları nedeniyle hayvanlar, davranışlarını gözlemleyerek hayatı daha iyi ve derinden öğrenen insanların ilk hayat ögretmenleri olarak saygı görmektedirler. Söz gelişi Yukarı Nil Vadisi'ndeki yerliler için babunlar tıpkı kadim Yunan'daki Hermes gibi ilahlar ile insanlar arasındaki bilgiyi, yazılı ve sözlü olarak taşıyan elçi rolündedir. ${ }^{25}$

Ölüm ve kaos hakkındaki mitlere göre hayat ve ölüm çatışmasını gidermek üzere Yüce Tanrı, bukalemun gibi bazı yavaş hayat süren hayvanları insanların sonsuza kadar sürecek dünya hayatına sahip olacağı müjdesini getirmek üzere bu dünyaya yollamaktadır. Bu hayvanın gökkuşağına benzer canlı renkleri haberin renkli oluşuna işarettir. Bu mitlere göre bukalemun insanın sorunlarına cevap vermede ağır davranınca Tanrı bu sefer yabani tavşan gibi sıçrayan hızlı

23. Kofi Opoku, "Animals in African Mythology", A Communion of Subjects: Animals in Science, Religion, and Ethics, ed. Paul Waldau - Kimberly Patton, (New York: Colombia University Press, 2006), s. 353.

24. James A. Serpell, "Attitudes Towards Animals", Encyclopedia of Animal Rights and Animal Welfare, (Westport: Greenwood Press, 1998), 76.

25. Denis Martin, "Animal Images", s. 55. 
bir hayvan göndererek ölüm haberini insanlara yollar. Tanrı, insana ebedî bir hayat dilemesine karşın insanın sebep olduğu doğadaki haksız olayların sonuçları yüzünden insan ölümlü bir varlık olmuştur. Bu bakımdan ölüm, bu mitlere göre doğadaki dışarıdan müdahale edilen düzensizliklerin doğurduğu kaosların neticesidir. Dahası insanın kavgacı oluşu ve çevresindeki doğaya karşı gaflet içinde bulunup doğaya zarar vermesi gibi hataları büyücüler temsili olarak canlandırmaktadır. Zira insan özelde hayvanların haklarını gözeten genelde doğayla uyumlu olan bir yaşam sürmelidir. ${ }^{26}$

Afrika yerli halklarındaki yaratılış mitolojilerinin bazısında hayvanların öz açısından masum oldukları, insanların onlara karşı açgözlü ve pervasız oldukları, Yüce Tanrı'nın insanların bu tavrından hoşnut olmadığı hatta öfkesine maruz kaldıkları gibi bir takım motiflere yer verilmektedir. ${ }^{27}$ Örneğin Sudan ve Uganda'da yaşayan, ama köken olarak Doğu Afrika yerli kabilelerinden Masaai sözel anlatısına göre başlangıçta yer ve gökler bir idi. Dünyada yaşayan hayvanlar Yüce Tanrı Ngai'ye aitti. Gökler ve yer birbirinden ayrışınca Yüce Tanrı Ngai ve onun sürü hayvanları artık yerde değil göklerde yaşamaya başladı. Yüce Tanrı, yerde yeterince ot bitirince, hayvanlarını yeryüzüne Masaai Kabilesi'ne gönderdi ve onlara hayvanları koruyup kollamalarını emretti. Hatta hayvanların korunma emrinin yerine getirilmesini somut olarak sağlamak üzere her bir hayvanın boynunda yabani incir ağacının köklerinden yapılmış uzun yularlar bulunmaktaydı. Bu yüzden Masaai kabile üyeleri bu ağacı kutsal kabul etmektedirler. ${ }^{28}$

Hayvanlarla ilişkili bir diğer yaratılış miti, Nguni/Zulu kabilesine aittir. Bu yerlilerin anlatılarında bu dünyada ilk ortaya çıkan mahluklar yukarıdan aşağıya sırasıyla atalar (amadlozi) yani yaşayan ölüler (abaphansi), insanlar (bantu veya muntu) son olarak hayvanlar (isilwane) ve diğer canlılar şeklindedir. Bu ontolojik hiyerarşi, ilginç bir ortaklık olarak hayvanları insanlardan hemen sonrasına getirmekte ve insanları hayvanlara karşı işlenen cezai suçluluk ve kınamaya hazırlıklı hâle dönüştürmektedir. Yine Zululara göre insanlar Tanrı'nın imgesinde yaratılmış olurken, hayvanlar, Yüce Tanrı'nın veya daha düşük ilahların sıfatlarını somut olarak temsil etmektedirler. Atalar, canlı ölüler olarak Afrika folklorunda Tanrı ile insanlar arasındaki temel bağlantıyı sağlayan köprü görevi gibi hayati bir rol oynarlar. Bunun yanında öfkelerinin dindirilmesi maksadıyla Yüce Tanrı'ya veya ölmüş atalara inek, boğa, keçi veya

26. Smart, Religions of the West, s. 246.

27. Kai Horsthemke, "Animals and African Ethics", Journal of African Ethics, 7 (2007), s. 124-125.

28. Ama Mazama, “Masaai”, Encyclopedia of African Religion, ed. Molefi Kete Asente Ama Mazama, (California: Sage Publishing, 2009), s. 397. 
koyun gibi hayvanların kurban olarak sunulduğu dinî törenler de söz konusudur. $^{29}$

Bir Afrika mitolojisinde bilhassa Gana ve Togo yerlilerinden olan Fon ve Ewe kabilelerine göre Yüce Tanrı Mawu'nun ikinci çocuğu olan Hebiosso, gök, şimşek ve yıldırım tanrısı olarak aynı zamanda adalet sağlayan ilke olup hayvanlara ve doğaya kötülük yapanları şiddetli bir şekilde cezalandırmaktadir. $^{30}$

Bir başka Afrika mitolojisine göre ise hayvanların kendilerine özgü dilleri vardır. Bilhassa hayvan sahibi insanlar devamlı olarak onlarla meşgul olduklarında onların konuşma tarzlarına aşina olabilir ve onların neyi kastettiklerini anlayıp onlara layık oldukları davranışı gösterebilirler. ${ }^{31}$

Afrika'da hayvanlar, günlük hayatta ve ekonomik hayatta olduğu kadar folklorik hayatta da önemli rol üstlenirler. Kozmik düzenin dengesi ve hayatın hiyerarşisi adına hayvanlar Yüce Varlık tarafından bir amaç uğruna yaratılmışlardır. Bilhassa totem olarak seçilen hayvanlar, Afrikalının doğaya olan pozitif yaklaşımını ortaya koymaktadır. Öyle ki Afrikalılar, hayvanlara totem bağlamında enkarne olmuş bir tanrının bir yüzü veya arketipi olarak saygı duymaktadırlar. Burada hayvanlar bizzat tanrı değildir, ama tanrının yeryüzüne yansıyan yönünü $(B a)$ oluşturduğu için değerlidirler. Bu yüzden Afrikalıların totem kabul edilen hayvanlara olan derin saygısı teolojik anlam içermektedir. Tanrılar ve insanlar gelecek hayatta veya öteki dünyada herhangi bir hayvanın formuna girebileceklerdir. Hayvanlara duyulan bu derin ve samimi sayg1 sebebiyle söz gelişi kedi gibi hayvanların cesetleri de tıpkı insan kadar saygı görmekte ve öteki dünyada aynı amaçlar için ölümsüzlüğe ulaşması maksadıyla korunmaktadır. ${ }^{32}$ Hayvana verilen değer, ilk etapta Afrika yerlilerinin selamlaşmasında kendisini gösterir. En tipik selamlama ifadesi olan "abela", basit "bir nasılsınız?" sorusundan ziyade aile üyelerinin, akrabaların ve hatta hayvanların durumunu da sormaktır. ${ }^{33}$

Afrika kültleri içinde bilhassa Nguni yerli kültüründeki Ubuntu (paylaşılan insanlık, insan olma bilinci, insani ilişkiler ağına bağlı olma) önemli yer tutmaktadır. Bir Afrika kültürel konsensüsü olarak Ubuntu'nun, kadim Misır'da-

29. Horsthemke, "Animals and African Ethics", s. 125.

30. Thomas Houessou - Adin, "Mawu-lisa", Encyclopedia of African Religion, ed. Molefi Kete Asente - Ama Mazama, (California: Sage Publishing, 2009), s. 413.

31. James MacDonald, "Manners, Customs, Superstitions, and Religions of South African Tribes", The Journal of the Anthropological Institute of Great Britain and Ireland, 20 (1891), 113-140.

32. Elizabeth Andrade, “Animals", Encyclopedia of African Religion, ed. Molefi Kete Asente - Ama Mazama, (California: Sage Publishing, 2009), s. 56-57.

33. Emmanuel Kombem Ngwainmbi, "Abela", Encyclopedia of African Religion, ed. Molefi Kete Asente - Ama Mazama, (California: Sage Publishing, 2009), s. 3. 
ki Maat fikri gibi, en geniş canlı ekolojik sistemiyle doğa ile uyumlu olmayı, kişinin etrafındaki çevreyle saygıya dayalı ahlaki ilişkisi ve doğruluk erdemi gibi işlevsel anlamları vardır. ${ }^{34}$

Malawai ve Bantu yerlileri başta olmak üzere çoğu yerlilerin ahlak anlayışında görülen boyutuyla aynı zamanda insan haysiyeti demek olan Bumuntu veya ahlaki karakteri anlamına gelen Muntu kavramları etrafında şekillenmektedir. Descartes' inkine benzer bir anlayışla, "Ben varım bu yüzden biz varız veyahut tam tersi biz varız çünkü ben varım" şeklinde interaktif bir perspektif bulunur. Böylece Ubuntu bir dünya görüşü olarak aynı zamanda Afrika insanını ve diğer varlıkları birleştirici bir karakter bahşederek dayanışmayı hatta ideolojik açıdan sömürge karşıtlığını örgütleyerek kendi doğasına uygun davranmayı ve dış âleme yönelik doğal bir varlık olarak hareket etmesini istemektedir. ${ }^{35}$

Hayvan hakları konusunda Afrika kültürel çevresinde geliştirilen başka önemli kült, Zimbabwe'deki Şona kabilesine ait Ukama terimi etrafinda şekillenmektedir. Ukama, insanların Tanrı, ruhlar âlemi, atalar ve bilhassa doğal çevreyle olan yakın ilişki durumunu ortaya çıkarır. Temel fikir şudur: Bireyler, içinde yaşadıkları doğal çevrede bir tür ilişkiler ağ 1 içinde hareket etmektedir. İnsan gerçek kimlik ve şahsiyetine bu doğal ilişkiler ağ 1 içinde kavuşmaktadır. ${ }^{36} \mathrm{Bu}$ terim yoluyla toplumsal dayanışma veya Afrika'ya özgü ilişkiye dayalı çevrecilik anlayışı geliştirmiş olan yerel kültler, insanları diğer ölüler ve canlılarla beraber kozmik bir topluluğa dönüştürmektedir. ${ }^{37}$

Mali' de ortaya çıkan bir inanca göre her insan ailesi, aslında mahlukata ait uzun silsilenin bir parçasıdır. Bir başka ifadeyle bir insan doğduğunda onun ikizi olan bir hayvan herhangi bir yerde doğmaktadır. Dolayısıyla Afrika'nın yerli inancında hayvanların haklarını korumak teolojik bir eyleme dönüşmektedir. ${ }^{38}$

Daha farklı kültlerden de söz edilebilir. Söz gelişi Alt-Sahra Afrika yerel halklarından Dogonlar atalar ile hayvanlar arasındaki bağı anlatan güçlü kültlere sahiptir. Onların dama adlı maskeli bayram ritüellerinde insan-hayvan ilişkisi gün yüzüne çıar. Öte yandan söz konusu kabilede hayvanlar bir millet olarak kabul edilmekte ve insanlara ihtiyaç anında yardımcı olan candan var-

34. Horsthemke, Animals and African Ethics, s. 3 ve 10.

35. Kayange - Makwinja, "Exploring the Ethical Basis of Animal", s. 35.

36. Munyaradzi. F. Murove, "An African Commitment to Ecological Conservation: The Shona Concepts of Ukama and Ubuntu", Mankind Quarterly, 45/2 (2004), s. 195-215.

37. Kai, "Animals and African Ethics", s. 134.

38. Willie Cannon - Brown, "Jola”, Encyclopedia of African Religion, ed. Molefi Kete Asente - Ama Mazama, (California: Sage Publishing, 2009), s. 354. 
l1klar olarak görülmektedir. ${ }^{39}$

Zaten Afrika yerel dinleri kendi ortak zihinsel birlikteliği ve ritüel çoğulculuğu içinde kendi birliğini doğanın tamamını canlandıran ruhlara yönelik ortak ilgisine borçludur. Bu biyolojik çeşitlilik ve ekolojik çoğulculukta insanlar, taşlar, ağaçlar, hayvanlar, ırmaklar ve dağlar hayatın devamlılığını sağlayan tek bir zeminde ortaklaşa dayanışma içinde bulunurlar. Bu devamlılığın merkezinde yaşamı oluşturan bu gruplarda aktif olarak bulunan ataların ruhları bulunmaktadır. Böylece doğadaki her varlık gibi hayvanlar da en hafif terimle saygıyı hem kutsal eylem olarak tapınmayı hak etmektedir. Neticede yeryüzündeki neredeyse tüm eylemler doğmamış, hayatta olan ve ölmüş olan varlıklara bağlı olarak sürüp gitmektedir. ${ }^{40}$

Yine Afrikalıların dünya görüşlerinde veya geleneksel dinlerinde totemlerin şamanlarca icra edilen kült rolleri, insanların derin saygı ve kutsiyet duymak üzere seçtiği obje ve canlılarla uyumlu olmayı, haklarına saygılı olmayı onları öz kültürel miras olarak savunup korumayı anlatmaktadır. Matopo Tepelerinde veya Zimbabve'deki kazılan arkeoloji sitelerindeki bulgular göstermektedir ki yarı insan-yarı hayvan şeklindeki şamanik ifadeler hayvanların varlıklarına saygı duymak üzere geliştirilmiş bilişsel ve kutsal manevi miras olarak nesilden nesile aktarılmaktadır. ${ }^{41}$

Afrikalıların geleneksel dinlerinde epistemolojik bilgiye ulaşma yollarından biri de bilişsel olarak ruhlar, atalar, ölü akrabalar, tanrılar ve tanrıçalar gibi doğaüstü varlıklarla iletişimdir. Bu tür doğaüstü varlıklar, insanlara bilgiyi getirirken doğrudan rüya veya vizyonu kullanırken dolaylı olarak medyumlar, falcılar veya hayvanlar gibi vasıtalar kullanarak hayatın olağanüstü yönlerini veya doğanın yorumlanmaya muhtaç taraflarını açıklarlar. ${ }^{42}$

Cochrane, folklorik açıdan dindarların yaşadığ 1 evlerde biyo-ekolojik faktörlerin göze çarptığından söz eder. Ikhaya adı verilen fiziksel mekân olarak anlaşılan evler kelimenin tam anlamıyla doğayla bütünleşik hayat ağına sahip mekânlardır. Bu evlerde toprak tarım ile işlenip bitkiler korunur, hayvanlar doğal bir ortamda yaşar. Bitkiler, ağaçlar özellikle de hayvanlar güçlü bir bağ ile yani mukaddes bir sistemle birbirine bağlı olup tamamı ev halkından kabul

39. John Grim, "Knowing and Being Known by Animals", A Communion of Subjects: Animals in Science, Religion, and Ethics, ed. Paul Waldau - Kimberly Patton, (New York: Colombia University Press, 2006), s. 384-385.

40. Asente - Mazama, "Introduction", XXI- XXII.

41. Vimbai Gukwe Chivaura, "Sacred, Grooves", Encyclopedia of African Religion, ed. Molefi Kete Asente - Ama Mazama, (California: Sage Publishing, 2009), s. 298.

42. Mutumbo Nkulu - N'Sengha, "Epistemology", Encyclopedia of African Religion, ed. Molefi Kete Asente - Ama Mazama, (California: Sage Publishing, 2009), s. 243. 
edilir. $^{43}$

Afrika yerel kültüründe hayvanlar insanlarla aynı çevreyi, aynı yetenekleri, aynı doğa şartlarını ve hayat tecrübelerini paylaşmaktadırlar. Hatta hayvanlar, insanlar anlamasalar bile kendilerine göre aynı hikmet kaynağını ve kaderi inşa etmekte ve gerçek dünyada insanlar tarafından gida, elbise ve taşımacılık gibi alanlarda faydalanılmasına rağmen insanoğlunun gerçek dostu ve onun hayattaki aynası olmayı sürdürmektedir. ${ }^{44}$

Hayvanların, Afrika sözel geleneğinde ve hikmetli atasözleri ajandasında simgesel yerlerinin oldukça pozitif olduğu ve bu durumun gerçek hayatta da karşılık bulduğu anlaşılmaktadır. Buna göre atmaca, sabrı; köpek ise ivedi şartlardaki ustaca davranmayı sembolize etmektedir. Yine karga, hikmetle özdeş iken, bizon vicdanlı olmakla birdir. Yarasa, diplomatik açıdan insanlarla ilişkilerdeki mahareti anlatırken, kartal hayatta ihtiyatlı olmanın önemini vurgulamaktadır. Leopar, azim ve kararlılığı anlamlandırırken papağan etkili ve güzel konuşmayı ifade etmektedir. Bu durum aynı zamanda Afrika'ya ait hikmetli sözlere de yansımaktadır. Söz gelişi "Leopar ümitsiz olduğunda ot yer." derken Afrikalı insanı, değişen şartlara ayak uydurma ihtiyacını kastetmektedir. Yine o, "Atın dört ayağı olsa da düşebilir." derken güçlü zamanlarda bile insanın sıkıntıya düşebilme ihtimalini göz önünde bulundurması gerektiğini anlatmaktadir. ${ }^{45}$

Neticede Afrika'daki teorik açıdan mit, kült ve folklorik olarak kendini ortaya koyan hayvan hak ve önemini vurgulayan insan davranışları, hayvanları gözeten ve onları düşünen bir anlayışta geliştirilmektedir. Böylelikle Afrikalı insanlar, etraflarındaki canlılardan bilhassa hayvanlardan bolca hikmet kaynakları keşfetmektedirler ve bu hikmet, insanların doğru bir şekilde hayat sürmesini kolaylaştırmaktadır.

\section{Afrika Ahlak Teolojilerinde Hayvan Hakları}

Ahlak teolojileri açısından Afrika kıtasında Afrikalılık veya Afrika ahlakı diye insanın ahlaki ilişkilerini düzenleyici kabileye ahlak gibi bir kavramdan söz edilebilmektedir. Bu moral dünya görüşüyle Afrika kıtası, geniş dil, kabile ve etnik farklılıklarına rağmen pek çok ortak noktaları olan ve büyük bir etnik ahlakın entegre ettiği geleneksel inanç sistemine sahiptir. ${ }^{46}$

43. James R. Cochrane, "Religion, Health, and Economy", The Wiley-Blackwell Companion to African Religion, ed. Elias Kifon Bongmba, (West Sussex: Blackwell Publishing, 2012), s. 434.

44. Opoku, "Animals in African Mythology”, s. 351.

45. Opoku, "Animals in African Mythology", s. 357.

46. A. C. Peterson, "Africa”, William \& Mary Environmental Law and Policy Review, 38/1 (2013), 87. 
Afrikalı insan, ahlaki açıdan kendine biçilen rolü yerine getirmek zorundadır. Ahlaki teolojide sorumluluklar ve vazifeler öncelikle Tanrı'ya daha sonra atalara, sonra yaşayan insanlara daha sonra hayvanlara ve en son diğer canl1lara yöneliktir. Kötülük, insana ait olarak ortaya çıkan Tanrı ile beraber bulunmayan bir özellik olmasına rağmen ahlaklı olmak, hayvanlar dâhil tüm yaratıklara karşı ilişkilerde de uygulanması gereken bir teolojik eylemdir. ${ }^{47}$

Afrika'nın geleneksel dinî etiğinin hayvanları da kapsayacak genişlikte olduğu görülmektedir. Buna göre Tanrı, hem insanların hem de hayvanların babasıdır (Ishe Wabantu n'ebintu). Bu açıdan doğal dünya içinde yaşayan tüm canlı ve cansız varlıklar bedenin ayrılmaz bir parçasıdır. Tanrı'nın doğası hatta insanın doğası bu bakımdan hayvanları, ağaçları ve diğer varlıkları içermekte ve ilahi varlığın evi olan kozmosu oluşturmaktadır. Bu bakımdan iyi bir kalbi olan bir insan (Mucima Muyampe), tüm insanlara, tüm hayvanlara ve tüm doğal âleme iyiliğini yayar. Ahlaki ve manevi değerlerle donanmış iyi bir insanın, hayvanlar ve diğer canlılara yönelik iyiliğinde dört temel unsur söz konusudur:

1. İyi düşünce ve iyi kalp.

2. İyi konuşma.

3. İyi eylemde bulunma.

4. İyi yöntemle davranma.

Bunlar aynı zamanda hem ataların istediği hem de Yüce Ruh ve Yüce Yaratıcı olan Shakapanga Vidye Mukulu'un iradesine göre işleyen bir insan olma sanatıdir. $^{48}$

Aslında Afrika'da tek bir ahlak sistemi yoktur aksine pek çok ahlaki bakış açısının senkretizmi bulunmaktadır. Bilhassa Afrika'nın Sahara altındaki bölgelerindeki toplulukların dinî kültürlerinde büyüleyici bir ortak ahlaki düzenlemeler dikkat çekmektedir. Bir bütün olarak Afrika moral teolojilerine baktığımızda genel olarak yerel inançlar ve kültürlerden hareketle ortaya çı-kan antropolojik ve sosyal uygulamalardan oluştuğunu ve mitler, halk masalları, tabular, halk inanışları, folklor ve atasözleri gibi etnografik verilerde kendini gösterdiğini görmekteyiz. Bu yerel ahlaki uygulamalar, politik nasyonalizm, sosyalizm ve çok kültürlülük gibi etkilerin yanında Hristiyanlık gibi misyoner karakterdeki dinin kaçınılmaz tesiriyle şekillenmiştir. ${ }^{49}$

Afrika moral teolojileri, anlaşıldığ 1 kadarıyla, insanın dışındaki varlıkları da, yani hayvanları ve doğadaki diğer canlıları da kuşatmaktadır. Dolayısıyla yerel ahlaki kurallar, insan ile insan olmayan canlılar arasındaki yakın ilişkileri düzenlemekte ve buradan hareketle insanı kendi atalarının da dahil olduğu

47. Horsthemke, "Animals and African Ethics", s. 125.

48. Mutombo Nkulu-N'Sengha, "Bumuntu”, Encyclopedia of African Religion, ed. Molefi Kete Asente - Ama Mazama, (California: Sage Publishing, 2009), s. 147.

49. Horsthemke, Animals and African Ethics, s. 1-3. 
ruhlar âlemiyle ilintili bir hayat sürmesini sağlamakladır. ${ }^{50}$

\section{Afrika'da Hayvan Hak İhlalleri, İthamlar ve Eleştiriler}

Batılı modern antropologların abartılı değerlendirmelerine baktığımızda Afrikalıların doğa ile ilişkileri ile Batılıların doğa ile ilişkilerindeki farklı anlayışlara ideolojik olarak yaklaştıklarını görebiliriz. Özellikle din bilimcileri açısından Afrika'yı, ilkel kültür ve vahşi düşüncelerin vatanı gören $E d w a r d B$. Tylor'un buna bağlı geliştirdiği animizm teorisi ve onun talebesi James G. Frazer gibi antropologların totem, büyü ve fetişizm gibi masa başı teorileri şimdilerde hem uygun olmayan hem de ciddiyetsiz ve sahte bilimsellik olarak değerlendirilmektedir. Öncelikle bilmeliyiz ki, biyo-fiziksel bir dünyada bulunan Afrika yerli geleneklerinin ruh inanc1, sanıldığı üzere kurgusal, sembolik veya metafor değil tamamen gerçektir. Kendi zengin ve gelişmiş dinî yaratıcılığına sahip olan Afrika inanç sistemlerini ilkelleştirme ve doğal hâli sebebiyle vahşileştirme çabaları da Batılı sömürgeci ideolojilerin doğal sonuçları olarak görülebilir. $^{51}$

Böylece Batı antropolojilerinin Afrikalıları insan kabul etmeyen veya gayri insani karakterlerde veyahut vahşi gören anlayışları modern felsefelerde de belirgin hâlde görülmektedir. Söz gelişi Hegel daha da ileri giderek Afrikalıların ruh bilincinden mahrum olduklarını, dolayısıyla panteizm gibi bir kavramın bu kıtada olamayacağını, bundan dolayı modern anlamda monoteizmin görülemeyeceğini savunmaktadır. Ona göre Yüce Varlık fikri, ancak ruh terimiyle veya olağanüstü bir güç olarak anlaşılabilir. Bu yüzden Hegel, dinin insandan daha yüksek bir şeyin varlığıyla başlamasına rağmen Afrika'nın bu güç algısindan mahrum olduğunu iddia etmektedir. Burada Hegel'in Afrikalılara yönelik en büyük suçlaması, onların kendilerini doğadan, hayvanlardan ve diğer varlıklardan üstün görmesi hatta kendilerini "doğanın mutlak hakimi” konumuna sokarak farklılaştırması neticesinde doğal dindarlıktan uzaklaşıp "yabanileştirmeleridir." 52

Aslında Afrikalı için hayvanlara karşı yaklaşım, kültürel emperyalizm ve sömürgecilik öncesinde ekolojik denge gözetilerek doğal bir hayat içinde normal insani değerlerle ifade edilirken endüstriyel amaçlar peşindeki beyaz renkli Avrupalı sömürgecilerin Afrika'ya ayak basmasından sonra açık hak ihlalleri görülmüştür. Söz gelişi Batılı sömürgeci politikalar ve ideolojilerin kültürel emperyalizmi neticesinde Afrikalı insanların kendi kültüründen uzaklaş-

50. C. Kwenda, "Affliction and Healing: Salvation in African Religion", Journal of Theology in Southern Africa, 103 (1999), s. 10.

51. Rooney, African Literature, Animals and Politics, s. 12-18.

52. Rooney, African Literature, Animals and Politics, s. 77- 178. 
masıyla beraber, ekolojik dengeyi bozucu, düzensiz sürek avları, ormanlık alanların yok edilip yeni tarım alanları açılması, hayvanları ortadan kaldıran biyo-kimyasal yapay madde kullanımı eko-biyolojik çeşitliliği değiştirebilmekte hatta türleri yok edebilmektedir. ${ }^{53}$

Afrika'nın geleneksel dinlerine yönelik ithamların başında kurban ritüellerinde hayvanların bolca kullanılması gelmektedir. Ancak modern Afrika uzmanlarına göre merhametsiz ve insanlıktan uzaklaştırıcı sömürgecilerin doğayı tahripleri ve beyaz tenli ırkçıların ayrımcılıkları aslında Afrika'nın geleneksel dinlerini de etkilemiş görünmektedir. Bilhassa Afrika'nın Alt-Sahara bölgelerinin biyo-ekolojik dünyasında özellikle hayvanlar yeni sömürgeci yaklaşımlardan fazlasıyla zarar görmektedir. Dolayısıyla doğa merkezli bir anlayıştan modern insan merkezli bencil tutumlara doğru bir kayma görülmekte ve hayvanların hayatını, özgürlüğünü ve doğal yaşam alanlarını kısıtlayıcı ve suiistimalci eğilimler göze çarpmaktadır. ${ }^{54}$

Bunun yanında sözlü olarak aktarılan Afrika geleneksel inanç sisteminin, kötü ruhlardan korunmak, tanrıları hoşnut etmek veya ölü ataları yardıma çağırmak, cenaze, doğum veya evlilik törenleri gibi ritüellerde hayvanların sürekli kurban objesi olarak boğazlanmasına izin vermesi hatta bunu kutsal kült hâline getirip talep etmesi gibi katı yerel uygulamalar, günümüzde sözde medenileşmiş veya modernleşmiş Afrikalı hayvan hakları savunucuları tarafından şiddetle eleştirilmektedir. ${ }^{55}$

Afrika'da bilhassa köle, kadın ve hayvan haklarını ihlallere karşı verilen mücadeleler modernleşme veya sekülerleşme bağlamında değerlendirilmekte ve hatta bir özgürlük mücadelesi olarak görülmektedir. Hayvanlar kendi hakları için mücadele edemediğinden onlar adına insanlar bu görevi üstlenmelidirler. Gittikçe modern dünyayla entegre olan bu toplumlarda hayvanlar adına girişilen hak arayışlarına düşünsel empati adı verilmektedir. ${ }^{56}$

\section{Sonuç}

Batılı sömürgeci antropoloji ve felsefelerin Afrika inanç sistemlerini herhangi yüksek ahlaki kurallardan yoksun olduğu şeklindeki öznel değerlendirmeleri veyahut ilkel, vahşi kültür veya yabani gelenek gibi ideolojik yaklaşımları bilinen bir gerçektir. Aslında sanıldığının aksine Afrika kıtasına ait tek bir

53. Paul Waldao, "Pushing Environmental Justice", A Communion of Subjects: Animals in Science, Religion, and Ethics, ed. Paul Waldau - Kimberly Patton, (New York: Colombia University Press, 2006), s. 636-637.

54. Horsthemke, "Animals and African Ethics", s. 125-130.

55. Horsthemke, "Animals and African Ethics", s. 125.

56. B. Nneji, "Eco-responsibility: The Cogency of Environmental Ethics in Africa", Essays in Philosophy, 11/1 (2010), s. 31-43. 
dinden veya kültürden bahsetmek hemen hemen imkânsızdır. Nitekim İlahi dinlerin teolojik açıdan Yüce Varlık'1 anlamlandırırken dogmatik, pratik ve tecrübi açıdan birbirinden farklılaşması gibi Afrika inanç sistemi de kendi biyo-ekolojik çoğulculuğu içinde farklı farklı kültürel çevrelerde, ama zengin kült uygulamaları ve anlayışları içinde birbirleriyle bağlantılı olarak değerlendirilmelidir.

En geniş anlamıyla doğa ile bütünleşen en dar anlamıyla çevreyle yakın ilişki içine giren insan modelini öne çıkaran Afrika yerel dinî kültürleri, bir boyutuyla insanlar ile hayvanların ekolojik ve biyolojik cemiyetçiliği olarak görülebilmektedir. Bu açıdan bakıldığında bu inançlar, geniş yelpazede mahlukatla insanın dayanışması olarak da düşünülmektedir. Bu anlayışa göre hayvanlar ontolojik olarak bilinçli bir şekilde insanların iletişim kurduğu ritüellerde önemli bir araç, mitolojilerde bilhassa yaratmada hayati vasıta, ilk insanlar için yakın dost ve ruhlar için elçiler olarak kabul edilmektedir. Son olarak Afrikalı insanın âlemi anlamlandırmada vazgeçilmez köşe taşı sayılmaktadır.

Ritüel açıdan sunulan hayvan kurbanları bir kenara bırakılırsa hayvan haklarına karşı her türlü ihlal, onları suiistimal veya eziyet, en doğal hâliyle Afrika kıtasına yabancı terimlerdir. Doğada, sözde vahşi yaşamın acımasızlığındaki denge, orada yaşayan insanlara da uyumlu bir şekilde yansımaktadır. Afrika geleneksel inanç sisteminde hayvanların doğaya sağladığı biyo-ekolojik katkılar, insanlarca mukaddes görülüp tabularla düzenlenmişken aynı zamanda sağladıkları yaşam kaynakları olarak da değerli kabul edilmiştir. Bu anlamda Afrika yerel kültürleri, diğer kıtalardakinden daha homojen doğa merkezli ve daha antropolojik bir kozmos anlayışına sahiptir.

Bu bakımdan diyebiliriz ki Afrika dinî-ahlaki sistemi, bir bütün olarak, insan, hayvan, bitki, dağ, ırmak gibi canlı veya cansız tüm varlı̆̆ kuşatmakta ve onların ontolojik hakkını koruyan bütüncül ve entegre edici bir sisteme dönüşmektedir. Hatta canlı derken Afrikalının bilinci, sadece insanı merkeze almamakta aynı zamanda insan, hayvan bitki terimlerini beraber kullanmaktadır.

Son olarak kimi Afrika uzmanlarına göre bu kıtadaki yerel inançlar; kendi dünya görüşüne veya ahlak teolojisine hatta kültlerine bağlı kalarak hayvanlara, çağdaş Batı dünyasından daha fazla haklar vermektedir. Zira sömürgeci ve evrimci antropolojilere sahip Batıl1 insan sadece kendisinden olan veya kendisine benzettiği insanlarla beraber kendi dünyasını inşa ederken, Afrikalı yerel insana göre gerçek hayat diğer canlılarla beraber inşa edilen tam ve doğru yansıtılmış doğadaki yaşamın bizzat kendisidir.

\section{KAYNAKÇA}

Elizabeth, Andrade. "Animals”. Encyclopedia of African Religion. Ed. Molefi Kete Asente - Ama Mazama. 55-57. California: Sage Publishing, 2009. 
Antonio, Edward, P. "Indigenous African Traditions as Models for Theorizing Religion", Religion Theory Critique- Classic and Contemporary Approaches and Methologies. ed. Richard King, 147- 154. New York: Colombia University Press, 2017.

Asente, Molefi Kete - Ama Mazama. "Introduction". Encyclopedia of African Religion. Ed. Molefi Kete Asente - Ama Mazama. XXI-XXX. California: Sage Publishing, 2009.

Asante, Molefi Kete. "Animism”. Encyclopedia of African Religion. Ed. Molefi Kete Asente - Ama Mazama. 58-59. California: Sage Publishing, 2009.

Asante, Molefi Kete. "Chiwara”. Encyclopedia of African Religion. Ed. Molefi Kete Asente - Ama Mazama. 163-165. California: Sage Publishing, 2009.

Antonio, Edward P. "Religion and the Environment". The Wiley-Blackwell Companion to African Religion. Ed. Elias Kifon Bongmba. 140-151. West Sussex: Blackwell Publishing, 2012.

Cannon, Brown - Willie. "Bull". Encyclopedia of African Religion. Ed. Molefi Kete Asente - Ama Mazama. 140-141.California: Sage Publishing, 2009.

Cannon, Brown - Willie. "Jola". Encyclopedia of African Religion. Ed. Molefi Kete Asente - Ama Mazama. 354-355. California: Sage Publishing, 2009.

Chivaura, Vimbai Gukwe. "Sacred, Grooves". Encyclopedia of African Religion. Ed. Molefi Kete Asente - Ama Mazama, 297-298.California: Sage Publishing, 2009.

Cochrane, James R. "Religion, Health, and Economy". The Wiley-Blackwell Companion to African Religion. Ed. Elias Kifon Bongmba. 430-442. West Sussex: Blackwell Publishing, 2012.

Grim, John. "Knowing and Being Known by Animals". A Communion of Subjects: Animals in Science, Religion, and Ethics. Ed. Paul Waldau - Kimberly Patton. 373-390. New York: Colombia University Press, 2006.

Goodall, Jane. "Foreword“. Encyclopedia of Animal Rights and Animal Welfare. Ed. Marc Bekoff. I-X. Westport: Greenwood Press, 1998.

Houessou - Adin, Thomas. "Mawu-lisa". Encyclopedia of African Religion. Ed. Molefi Kete Asente - Ama Mazama. 412-413. California: Sage Publishing, 2009.

Horsthemke, Kai. "Animals and African Ethics". Journal of African Ethics 7 (2007), 119147. 2015.

Horsthemke, Kai. Animals and African Ethics. New York: Palgrave Macmillan Publishing,

Kayange, Grivas M - Simon Makwinja. "Exploring the Ethical Basis of Animal". Journal of Humanites (Zomba) 24 (2016), 2943.

Affliction and healing: Salvation in African Religion. Journal of Theology in Southern Africa, 103, 1-12.

Martin, Denisin. “Animal Images”. Encyclopedia of African Religion. Ed. Molefi Kete Asente - Ama Mazama. 54-55.California: Sage Publishing, 2009.

Mazama, Ama. "Masaai". Encyclopedia of African Religion. Ed. Molefi Kete Asente - Ama Mazama. 397-398. California: Sage Publishing, 2009.

MacDonald, James. "Manners, Customs, Superstitions, and Religions of South African Tribes". The Journal of the Anthropological Institute of Great Britain and Ireland 20 (1891), 113140 .

Murove, Munyaradzi F. "An African Commitment to Ecological Conservation: The Shona Concepts of Ukama and Ubuntu". Mankind Quarterly 45/2 (2004), 195-215.

Nneji, B. "Eco-responsibility: The Cogency of Environmental Ethics in Africa". Essays in Philosophy 11/1 (2010), 31-43.

Nkulu - N'Sengha, Mutombo. "God". Encyclopedia of African Religion. Ed. Molefi Kete Asente - Ama Mazama. 281-293. California: Sage Publishing, 2009.

Nkulu - N'Sengha, Mutombo. "Bumuntu". Encyclopedia of African Religion. Ed. Molefi Kete Asente - Ama Mazama. 142- 147. California: Sage Publishing, 2009. 
Nkulu - N'Sengha, Mutombo. "Epistemology". Encyclopedia of African Religion. Ed. Molefi Kete Asente - Ama Mazama. 242-245. California: Sage Publishing, 2009.

Ngwainmbi, Emmanuel Kombem. "Abela”. Encyclopedia of African Religion. Ed. Molefi Kete Asente - Ama Mazama. 2-3. California: Sage Publishing, 2009.

Peterson, A. C. "Africa". William \& Mary Environmental Law and Policy Review 38/1 (2013), 81-117.

Opoku, Kofi. "Animals in African Mythology", A Communion of Subjects: Animals in Science, Religion, and Ethics. Ed. Paul Waldau - Kimberly Patton. 351- 359. New York: Colombia University Press, 2006.

Serpell, James A. "Attitudes Towards Animals". Encyclopedia of Animal Rights and Animal Welfare. Ed. Marc Bekoff, 76-78. Westport: Greenwood Press, 1998.

Smart, Ninian. Religions of the West, New Jersey: Prentice Hall, 1994.

Spell, James a. "Attitute Towards Animals." Encyclopedia of Animal Rights and Animal Welfare. Ed. Marc. Bekoff. Westport: Greevwood Press 1998, s. 76, 78.

Taringa, Nisbert. "How Environmental is African Traditional Religion?". Exchange 35/2 (2006), 191-214.

Waldao, Paul. "Pushing Environmental Justice". A Communion of Subjects: Animals in Science, Religion, and Ethics. Ed. Paul Waldau - Kimberly Patton. 629-642. New York: Colombia University Press, 2006.

Yount, Lisa. Animal Rights, New York: Infobase Publishing, 2008. 